\title{
Application of National Education Technology Standards as Perceived by Nursing Students and Its Relation to Their Problem Solving Skill during COVID 19 Disaster
}

\author{
Ayat Fawzy Ghazala ${ }^{1 \& 2} \&$ Shimaa Ebrahim Elshall ${ }^{3}$ \\ ${ }^{1}$ The Education and Psychology Department, Faculty of Science and Arts, Jouf University Affiliation, Saudi Arabia \\ ${ }^{2}$ Department of Education Technology and Computer, Faculty of Specific Education, Menoufia University, Egypt \\ ${ }^{3}$ Nursing Administration Department, Faculty of Nursing, Menoufia University, Egypt \\ Correspondence: Shimaa Ebrahim Elshall, Nursing Administration Department, Faculty of Nursing, Menoufia \\ University, Egypt.
}

Received: October 1, 2020

doi:10.5430/ijhe.v10n2p172
Accepted: December 1, 2020

Online Published: December 3, 2020

\begin{abstract}
With the emergence of COVID 19 disaster, dependence on technological and electronic learning is increasing. National Education technology standard has a great impact on improving students' skills. One of these skills is problem solving which is very crucial to nurse student to be prepared to be professional nurse. This study sought to assess application of national education technology standards as perceived by nursing students and its relation to their problem solving skill during COVID 19 disaster. The study adopted a descriptive correlational design using a convenience sample (N $=218$ ) of all fourth nursing students who accept to participate in the study at Faculty of Nursing, Menoufia University. The instruments used to gather the data were developed questionnaire by researchers to assess application of national education technology standards, and problem solving skill questionnaire. The results show that the majority of nursing students have high level of perception regarding application of these standards. Moreover, the high percentage of nursing students had high level problem solving skill, and there was a positive moderate correlation between total score national education technology standards, and total score problem solving skill. Based on the findings, it is very important to ensure application of national education technology standards for teaching staff and administrative system. Moreover, Periodic updates and training on the new changes in education technology for both nursing students and teaching staff.
\end{abstract}

Keywords: COVID 19, national education technology standards, nursing students, problem solving skill

\section{Introduction}

\subsection{Background to the Study}

At the present time, the world has encountered by the COVID19 virus, which the World Health Organization identified it as a newly discovered virus that is a strain of Corona viruses, and there was no knowledge of it before it appeared in Wuhan, China in December 2019. Covid-19 is now a pandemic affecting many countries of the world. (World Health Organization, 2019). The consequences of a pandemic are unstoppable and uncontrollable for many countries of the world. Later on, almost many countries have stopped face-to-face learning; approximately a billion students' education is effected worldwide with COVID-19. Most of the higher education system is operating through the E-learning (AzziHuck \& Shmis 2020; Shahzad et al. 2020a, c). Moreover, as a response to COVID-19, most nations have applied severe social separating measures and a lockdown strategy. Clearly, this pandemic has tremendously affected schools, understudies, and educators. The utilization of technology improves the quality degree of learning and teaching among the partners. Electronic learning (E-Learning) has been viewed as the most ideal way to deal with proceed with the teaching and learning process during the pandemic (Octaberlina \& Muslimin, 2020).

Periodic updates and training on the new changes should be made to the university's e-learning platforms, provision of timely technical support to academics in order to sustain positive user experiences of e-learning were recommended (Maphalala \& Adigun, 2020). Sroeckl (2016) stated that the importance of using international technology education standards ISTE for students are preparing empowered students ready for the future to centralize student learning and thus be more prepared to enter the job market, success and excellence. Moreover, the use of technology that combines 
digital and physical life has become an essential part of students 'lives, helping them understand the way the digital world works and realizes digital citizenship for them. Lastly it results in developing the teaching and learning processes, and paying attention to the teaching process, not just its tools.

The skills of using technology are one of the important and main things that will enable graduates to meet the challenges of working today, with the need to provide tools and requirements to use technology to provide the best education (Oviawe, 2016). Using education technology improves various skills of students like critical thinking, problem solving as they search about the information using brain storming and other methods to solve any problem they face. (Adams et al. 2018; Chopra et al. 2019). These skills are very crucial specifically to nursing students. Medical care in 21 stcentury has accelerated the departmentalization and specialization of health care field. Consumers demand more qualitative medical services. In this situation, nurses should offer various nursing services with professional role and competency. Nursing units has been characterized as being uncertainty and instability. Therefore, problem solving ability is emphasized in order to solve the problem including client's health treatment and needs (Sook \& Hyun ,2014).

Not only electronic learning but also ISTE Standards are standards for the use of technology in teaching and learning (technology integration). They include the ISTE Standards for Students, which show competence expected of students. They also include Educator Standards, Administrators Standards. The ISTE Standards are designed to work with new and various learning methods. In addition, they are supporting using of new approaches to education; including, electronic learning, blended learning, flipped classroom model and project based learning (ISTE, 2016).

Nursing education is one of the branches of vocational education, which has an important role in preparing the workforce in the nursing profession, and as a result of the development of technologies and their use in the learning process, this led to the development of nursing education skills, and provided an opportunity for students to develop their professional and personal skills The skill of solving clinical problems for students of nursing education is acquired by students from effective experiences in the life situations they direct and includes a set of steps which are feeling the problem, identifying the problem, gathering information, setting assumptions, choosing them and analyzing the results to reach generalizations, and all this in the patient's vital signs unit and care for the course of practical nursing basics (Sammour \& Al-Qaisi, 2011).

Clearly E-learning is covered under a larger term of technology-based learning through websites, learning portals, video conferencing, YouTube, mobile apps, and thousand types of free available websites for blended learning tools. Currently, E-learning has great benefits like enhancing students' knowledge, even the academic staff and professional and industry people skills through the internet. There is a significant difference between traditional learning and elearning. In traditional classrooms, teachers become role models who play an important role in imparting knowledge to students. In this class, the lecturer is someone who knows and understands the learning situation. In the other hand, learning with e-learning focuses more on students. Students are required to be responsible and independent in carrying out learning. This atmosphere makes students more active in designing the material and reviewing it and developing knowledge according to their own efforts and initiatives. (Adams et al. 2018; Chopra et al. 2019).

To gain the advantages of learning using technology, application of The International Standards for Education Technology this is what the organization asserts that (ISTE ,2016). It provides the skills that help students engage in the world of digital communication. These standards are designed for all students in educational stages and throughout the world to employ them during the student's learning period thus students will be responsible for their learning in an innovative framework which leads to amplifying learning and prosperity by working. The International Association for Technology in Education is considered one of the most important international organizations interested in the educational process, and its headquarters is in the United States of America, not aiming for material profit but rather to effectively employ technology standards, tools and applications for students, teachers, administrators, computer science teachers and technology trainers, in order to Providing an innovative teaching and learning environment( Curwin et al. ,2018).

The ISTE Standards are a framework for innovation in education. The Educator and Student Standards empower teachers, coaches, and administrators to move instructional technology from niche innovation to mainstream practice. The standards provide a common language for teachers to plan curriculum and design lessons incorporating technology. Student Standards were developed as today's students must be prepared to thrive in a constantly evolving technological landscape. The ISTE Standards for Students are designed to empower student voice and ensure that learning is a student-driven process. The Standards for Educators are a teacher's road map to helping students become empowered learners. These standards will deepen educator practice, promote collaboration with peers, challenge you to rethink traditional approaches and prepare students to drive their own learning. The Standards for Education Leaders 
support the implementation of the ISTE Standards for Students and the ISTE Standards for Educators and provide a framework for guiding digital age learning (21CLI, 2018).

The International Standards for Education Technology for Students consists of 7 main standards and subcategories of these (ISTE ,2016). First standard is an empowerment student: In order for the student to benefit from the techniques, who is active in the process of learning and achieving goals. Second standard, a Digital Student: The student learns about his rights and duties to learn in a digital world in a safe, legal and ethical way. Third standard, Knowledge Productive Student: The student uses digital tools to build knowledge creatively through purposeful learning experiences. Fourth standard, an innovative student and designer: The student uses technologies to identify problems and provide new and innovative solutions.

In addition, the fifth standard, Student with computer thinking: The student uses technological methods to develop solutions to solve problems. Sixth standard, an innovative student in communication: The student uses digital tools, patterns and media to achieve creative communication with others. Finally, the seventh standard, an international associate student: The student uses digital tools to enrich learning in cooperation with others and work in local and international teams.

There are many studies that have focused on studying the international standards for education technology (ISTE) among students in different fields and levels, including a study (Hakami, 2019). This study recommended that the need to pay attention to the technical skills of students of international standards for education technology ISTE for students to work to instill and align them with the local environment and provide the requirements for the adoption of these standards to provide students with the necessary technical skills and their impact on the education process, and students should be familiarized with these international standards by holding training courses For them, and to study the availability and the international standards of technology for students of other universities. Moreover, Ayad \& Ajrami study (2017) stated the necessity of holding training courses for both students and teachers about the importance of applying the standards to education, and the study recommended that research should pay attention to the standards because of their importance in education.

Dondlinger et al. (2016) sought to determine the extent to which sixth-grade students use mathematics ISTE standards, by analyzing students 'data in interviews about ISTE standards showing that students' standards are met by a strong degree, and the study made several recommendations It is conducting future research on the extent of application of the standards beginning and end of the academic year and achieving the implementation of the standards in educational environments and specializations and other geographical regions, the study also stresses the need to conduct more research on the extent to which ISTE standards are used for students as a powerful tool to measure and evaluate the success of technology in education rather than relying on Test scores are only for evaluation.

A study Kurt et al. (2008) also recommended the importance of providing practical applications by employing technology in education and students' daily lives, and verifying this by comparing their level of technology provides with international standards for technology education for students. Nursing is one of the sciences that combine an educational and clinical offender, Landers (2000) states that the nursing profession depends on the numbers of students enrolled in it to practice and improve their practical skills.

In order for the practical side to be effective, it must be linked to vocational education with the educational goals and content in the field of nursing, and is consistent with modern technology, and seeks to develop students' performance and behavioral capabilities together taking into account their inclinations, abilities and educational needs (Al-Ani \& Al-Jamili, 2000). Problem solving skill is one of the basic nursing skills that enable students to face the health problems experienced by the patient, discover them when measuring them, determine the cause of the patient's health defect and find the necessary solutions (Landers, 2000). Problem solving is defined as the set of operations and steps identifying and diagnosing the problem, developing solutions and alternatives, choosing the best solution, putting the solution into practice, and evaluating the solution (Mohammed, 2017).

There are many studies reported that the importance of developing the skill of solving clinical problems among nursing college students and sought to develop them, including the study of Sammour \& Al-Qaisi (2011), the study of Oldenburg \& Hung (2010), the study of Helen et al. (2009). Moreover, AL-Zabon \& Al-Ajlouni (2015) stated that the problem-solving skill is a basic skill in both basic, secondary and university learning for both males and females, and the study also demonstrated the effectiveness of using electronic technologies to improve students' problem-solving skills at the university. Furthermore, Serin (2011) demonstrated that integrating a computer and its techniques into teaching has to do with problem-solving skills and has led to their development and increased achievement for students. 
Additionally a study of Bixler \& Land (2010) that aimed to identify the impact of employing electronic environments in solving open problems among students of the IT and science track. The results showed a clear superiority to solve problems for the experimental group over the control group students and these confirms the importance of skill training Solve problems and employ electronic environments. Oldenburg \& Hung (2010) also stressed the need to pay attention to the development of clinical problem-solving skills among nursing students, and the effectiveness of using the problem-solving method via the Internet and its techniques in arriving at better results to solve problems facing legal nursing students instead of the traditional lectures method.

\subsection{Significance of the Study}

COVID 19 has had a great impact on the education process in many countries, including Egypt, the education has moved virtually from class to electronic and distance education. Therefore, students must possess the academic ability to use modern technologies and communication and to master the skills of interaction and learning with these technologies in order to be able to harmonize with this development and coexistence in this age. Furthermore, many literatures ascertain the importance of using international technology standards for education in the process of education and developing technological skills for students and the need to take care of them and work to achieve them to raise the quality of education in various fields (AL- Fleet, 2019; Bajabaa, 2017). Moreover, Rahman (2014) stated that employing modern technology in education helps students in developing problem-solving skills, critical thinking, communication, and increases their motivation to learn. Problem solving is a key requirement of professional nursing practice. So, we should sure that our nursing students have this skill. In Egypt there is lack of study regarding this point of research. So, the present study will be done to assess application of national education technology standards as perceived by nursing students and its relation to their problem solving skill during COVID 19 disaster

\subsection{Aim of the Study}

The aim of the present study is to assess application of national education technology standards as perceived by nursing students and its relation to their problem solving skill during COVID 19 disaster.

\subsection{Research Questions}

The present study seeks to answers to the following research questions:

1. What are nursing students' perception levels regarding application of national education technology standards during COVID19 disaster?

2. What are nursing students' levels regarding problem solving skill during COVID19 disaster?

3. Is there a relationship between application of national education technology standards as perceived by nursing students and their problem solving skill during COVID19 disaster?

4. Is there a relationship between application of national education technology standards as perceived by nursing students, their problem solving skill, and their demographic data during COVID19 disaster?

\section{Method}

\subsection{Types of Research}

A descriptive correlational research design through self-administered questionnaires was used to assess application of national education technology standards as perceived by nursing students and its relation to their problem solving skill. Regarding Setting of the research, the present research was implemented at Faculty of Nursing, Menoufia University, which is affiliated to Ministry of Higher Education, Egypt.

\subsection{Participants}

A convenience sample (218) of all fourth nursing students enrolled in the second semester academic year 2019/2020 at nursing administration department at Faculty of Nursing, Menoufia University who accepted to participate in this study. The participation was voluntary and anonymous.

\subsection{Data Collection Tools}

Two tools were applied in this research in addition to the demographic data.

\subsubsection{Tool I: National Education Technology Standards Questionnaire}

It consisted of two portions as the following:

\section{Part I: Socio- demographic data:}

This instrument was designed by the researchers to gather the socio- demographic data of the study participants (age, 
sex, and residence).

\section{Part II: National Education Technology Standards questionnaire (NETS):}

Structured questionnaire developed by the researchers based on literature review (The International Society for Technology in Education (ISTE) developed the ISTE Standards 2016, formerly known as the National Educational Technology Standards (NETS). It includes (7) standards with 33 items to assess National Education Technology Standards application as Perceived by Nursing Students

\begin{tabular}{ll}
\hline National Education Technology Standards & Number of items \\
\hline Standard 1: an empowerment student & 5 items. \\
Standard 2: a digital student & 4 items \\
Standard 3: a knowledge productive student & 4 items \\
Standard 4: an innovative student and designer & 5 items \\
Standard 5: a student with computer thinking & 6 items \\
Standard 6: an innovative student in communication & 4 items \\
Standard 7: an international associate student & 5 items \\
Total & 33 items \\
\hline
\end{tabular}

Scoring system:

Each statement response is measured on three points Likert Scale that ranged from (2) agree (1) uncertain and (0) disagree. The scoring system was followed to obtain perception level of application.

$<65 \%$ of total score $\rightarrow$ Low perception.

$65-75 \%$ of total score $\rightarrow$ Moderate perception.

$>75 \%$ of total score $\rightarrow$ High perception.

- Validity of Instrument

The validity of the NTS was done by five experts (one professor and two assist Professors in Nursing administration and two assist Professors in Community health nursing) who interviewed the instrument for content accuracy and internal validity. Also, professors were asked to judge the items for completeness and clarity (content validity). Suggestions were incorporated into the instrument.

- $\quad$ Reliability of Instrument

Reliability was estimated among 10 nursing students by using test retest method with two weeks apart between them. Then Cronbach alpha was calculated between the two scores. It was 0.952 which indicates that the instrument is reliable to detect the objectives of the study.

\subsubsection{Tool II: Problem Solving Skill Questionnaire}

Structured questionnaire developed by Mohammed (2017) based on literature review. It consisted of 32 items, to assess problem solving skill divided into five categories;

\begin{tabular}{ll}
\hline Problem solving skill categories & Number of items \\
\hline 1: identify the problem & 7 items. \\
2: put solutions and alternatives & 8 items \\
3: choose the best solution & 7 items \\
4: put the solution into practice implementation. & 4 items \\
5: evaluate the solution. & 6 items \\
Total & 32 items \\
\hline
\end{tabular}

\section{Scoring system:}

Each statement response is measured on three points Likert Scale that ranged from (2) often (1) sometimes and (0) rarely. The scoring system was followed to obtain assessment problem solving skills for nursing students.

$<65 \%$ of total skills score $\rightarrow 42$ point $\rightarrow$ Low problem solving skills. 
$65-75 \%$ of skills score $\rightarrow 42-48$ point $\rightarrow$ Moderate problem solving skills.

$>75 \%$ of total skills score $\rightarrow 48$ point $\rightarrow$ High problem solving skills.

The validity and reliability of this scale. The tool is used as it is valid and reliable.

\subsection{A Pilot Study}

A pilot study was performed on 20 nursing students in the study sample to examine the practicability and applicability of the study tools, identify any problems, and estimate the time needed to fill in the questionnaire. Based on the results of the pilot study, there is no modification and clarification of any questions was done so they included in the study sample

\subsection{Ethical Considerations}

The current study was approved by Faculty of Nursing Institutional Research Board (IRB) committee. The ethical approval was also obtained for data collection. Voluntary participation and withdrawal from the study were assured to all participants. Moreover, confidentiality was assured by telling all participants that their information was used for the research purpose only. The aim of the study and the method of completing the questionnaires were clearly explained for all participants. Oral consent was approved from each participant before administration of the questionnaires.

\subsection{Data Collection}

Because of COVID 19 and its effect on educational process and application electronic education, so we used internet communication as the data was collected via developing application web site on Google groom and send it to all nursing student through clinical Whats Aapp and Facebook group, student email and other method of internet communication. Researchers explained the purpose of the study through these methods of communication and provided a consent form, with a request for the recipient to participate in the study. The time for data collection was two weeks.

\subsection{Statistical Analysis}

Data was analyzed by using SPSS (Statistical Package for Social Science) statistical package version 20. Graphics were done using Excel program. Quantitative data were presented by mean (X) and standard deviation (SD). Qualitative data were presented in the form of frequency distribution tables, number and percentage. It was analyzed by chi-square $(\chi 2)$ test. However, if an expected value of any cell in the table was less than 5, Fisher Exact test was used (if the table was 4 cells), or Likelihood Ratio (LR) test (if the table was more than 4 cells). Level of significance was set as $P$ value $<0.05$ for all significant tests.

\section{Results}

\subsection{Demographic Data}

The average age of the studied sample was $(22.2 \pm 1.1 \mathrm{Y})$. The high percentage of nursing student $(68.8 \%)$ was from (21 to 22 ) years and (31.2\%) was from (22 to 23 ) years. Regarding participant gender, the majority of nursing students $(83.5 \%)$ was female and only $(16.5 \%)$ was male. In relation to studied sample residence, the majority of nursing students (84.4\%) was rural and only (15.6\%) was urban.

\subsection{Nursing Students' Perception Levels Regarding Application of National Education Technology Standards}

Table 1 demonstrated levels and mean score of the seven National Technology Standards as perceived by nursing students and their grand total score, during COVID 19 disaster. As shown in the table the grand total mean and range of nursing students' perception of Application of National Education Technology Standards was $(57.5 \pm 15.4)$. Moreover, the high percentage of high perception (85.3\%) was to standard 2(a digital student). While the standard 7 (An international associate student) has high percentage (18.3\%) of low perception of application. Regarding moderate perception the high percentage (11.9\%) was to standard 1(An empowerment student)

Figure (1) showed the total Levels of application of National Technology Education Standards as perceived by nursing students. As noticed in the figure, the majority of nursing students $(82.6 \%)$ have high level of perception regarding application of these standards. Furthermore, only (1.8\%) has low level of perception regarding it.

\subsection{Nursing Students' Levels Regarding Problem Solving Skill}

Table 2 presented levels and mean score of five problem solving skill categories among nursing students and their grand total score, during COVID 19 disaster. As noticed in the table the grand total mean and range of nursing students' five problem solving skill categories was $(46.1 \pm 10.2)$. Moreover, the high percentage of high perception $(43.1 \%)$ was to problem solving skill category four (Put the solution into practice implementation). While the problem solving skill category five (Evaluate the solution) has high percentage (43.1\%\%) of low perception of application. 
Table 1. Levels and mean score of the seven National Education Technology Standards as perceived by nursing students and their grand total score and levels, during COVID 19 disaster $(\mathrm{N}=218)$.

\begin{tabular}{|c|c|c|c|c|c|c|c|}
\hline \multirow[t]{2}{*}{$\begin{array}{l}\text { NTSs and grand total } \\
\text { score }\end{array}$} & \multicolumn{2}{|c|}{$\begin{array}{l}\text { Low NTS } \\
\text { perception }\end{array}$} & \multicolumn{2}{|c|}{$\begin{array}{c}\text { Moderate NTS } \\
\text { perception }\end{array}$} & \multicolumn{2}{|c|}{$\begin{array}{l}\text { High NTS } \\
\text { perception }\end{array}$} & \multirow{2}{*}{$\begin{array}{c}\text { Total mean score } \\
\text { of each/total NTS } \\
\text { Mean } \pm \text { SD } \\
\text { (Range) }\end{array}$} \\
\hline & No & $\%$ & No & $\%$ & No & $\%$ & \\
\hline 1. Stander 1 & 36 & 16.5 & 26 & 11.9 & 156 & 71.6 & $\begin{array}{c}8.6 \pm 2.4 \\
(0-10)\end{array}$ \\
\hline 2. Stander 2 & 14 & 6.4 & 18 & 8.3 & 186 & 85.3 & $\begin{array}{c}7.3 \pm 1.7 \\
(0-8)\end{array}$ \\
\hline 3. Stander 3 & 22 & 10.1 & 24 & 11 & 172 & 78.9 & $\begin{array}{c}7.1 \pm 1.8 \\
(0-8)\end{array}$ \\
\hline 4. Stander 4 & 38 & 17.4 & 12 & 5.5 & 168 & 77.1 & $\begin{array}{c}8.7 \pm 2.1 \\
(0-10)\end{array}$ \\
\hline 5. Stander 5 & 38 & 17.5 & 16 & 7.3 & 164 & 75.2 & $\begin{array}{c}10.3 \pm 3.5 \\
(0-12)\end{array}$ \\
\hline 6. Stander 6 & 34 & 15.6 & 16 & 7.3 & 168 & 77.1 & $\begin{array}{c}6.9 \pm 2.1 \\
(0-8)\end{array}$ \\
\hline 7. Stander 7 & 40 & 18.3 & 10 & 4.6 & 168 & 77.1 & $\begin{array}{c}8.7 \pm 2.6 \\
(0-10)\end{array}$ \\
\hline Grand total NTS groups & 34 & 15.6 & 4 & 1.8 & 180 & 82.6 & $\begin{array}{c}57.5 \pm 15.4 \\
(6-66)\end{array}$ \\
\hline
\end{tabular}

\section{口Low NTS perception \\ 口Moderate NTS perception \\ 口High NTS perception}

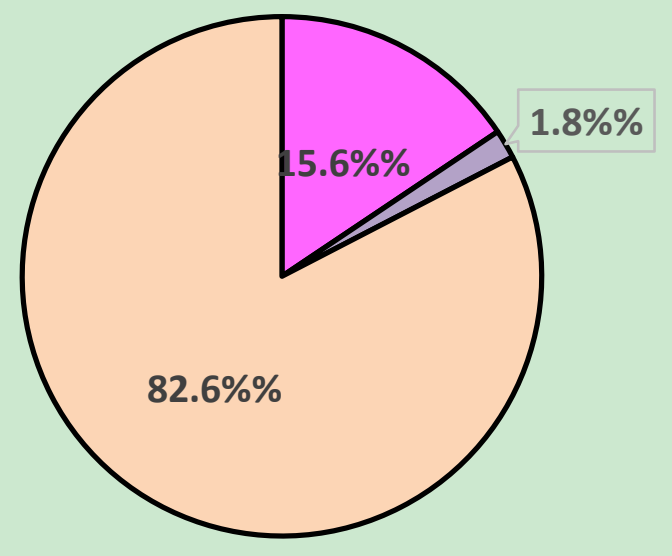

Figure 1. Levels of National Education Technology Standards as perceived by nursing students $(\mathrm{N}=218)$ 
Table 2. Levels and mean score of five problem solving skill categories among nursing students and their grand total score and levels, during COVID 19 disaster( $\mathrm{N}=218)$.

\begin{tabular}{|c|c|c|c|c|c|c|c|}
\hline $\begin{array}{l}\text { Nursing students' problem solving skills } \\
\text { categories: }\end{array}$ & \multicolumn{2}{|c|}{ Low PSS level } & \multicolumn{2}{|c|}{ Moderate PSS level } & \multicolumn{2}{|c|}{ High PSS level } & \multirow{2}{*}{$\begin{array}{c}\text { Total mean score } \\
\text { of each } \\
\text { subscale/total } \\
\text { political skill } \\
\text { Mean } \pm \text { SD } \\
\text { (Range) }\end{array}$} \\
\hline & No & $\%$ & No & $\%$ & No & $\%$ & \\
\hline 1. Identify the problem (7items) & 80 & 36.7 & 60 & 27.5 & 78 & 35.8 & $\begin{array}{c}9.8 \pm 2.9 \\
(0-14)\end{array}$ \\
\hline 2. Put solutions and alternatives (8 items) & 82 & 37.6 & 48 & 22 & 88 & 40.4 & $\begin{array}{c}11.4 \pm 3 \\
(3-16)\end{array}$ \\
\hline 3. Choose the best solution ( 7 items) & 82 & 37.6 & 56 & 25.7 & 80 & 36.7 & $\begin{array}{c}10.1 \pm 2.7 \\
(0-14)\end{array}$ \\
\hline $\begin{array}{l}\text { 4. Put the solution into practice } \\
\text { implementation (4 items) }\end{array}$ & 40 & 18.3 & 84 & 38.5 & 94 & 43.1 & $\begin{array}{c}6.0 \pm 1.6 \\
(0-8)\end{array}$ \\
\hline 5. Evaluate the solution (6 items) & 94 & 43.1 & 58 & 26.6 & 66 & 30.3 & $\begin{array}{c}8.6 \pm 2.5 \\
(0-12)\end{array}$ \\
\hline Total PS skill groups & 69 & 31.7 & 43 & 19.7 & 106 & 48.6 & $\begin{array}{c}46.1 \pm 10.2 \\
(11-65)\end{array}$ \\
\hline
\end{tabular}

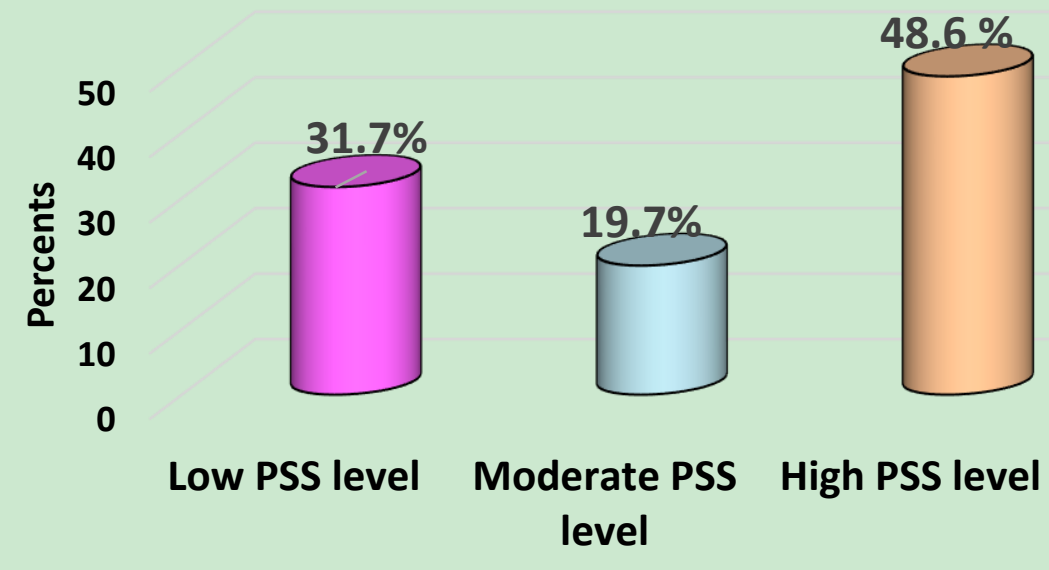

Figure 2. Levels of Problem-Solving Skill among nursing students $(\mathrm{N}=218)$

Figure 2 demonstrated the total levels problem-solving skill of nursing students. As showed in the figure, the more of half of nursing students have high and moderate level regarding problem solving skill. Furthermore, only (31.7\%) has low level regarding it. The high percentage of nursing students (48.6\%) had high level problem solving skill. 
3.4 Relation between Application of National Education Technology Standards as Perceived by Nursing Students and Their Problem Solving Skill

Table 3. Relation between application of national education technology standards as perceived by nursing students and their problem solving skill during COVID-19 disaster ( $\mathrm{N}=218$ )

\begin{tabular}{|c|c|c|c|c|c|c|c|c|c|}
\hline \multirow{4}{*}{$\begin{array}{l}\text { Groups of grand total } \\
\text { National technology } \\
\text { standards }\end{array}$} & \multicolumn{6}{|c|}{ problem-solving skills } & \multicolumn{2}{|c|}{ Total } & \multirow{4}{*}{$\begin{array}{l}P \text { value of } \\
\text { difference }\end{array}$} \\
\hline & \multirow{2}{*}{\multicolumn{2}{|c|}{$\begin{array}{l}\text { Low } \\
\text { problem } \\
\text { solving } \\
\text { skills(0-41) }\end{array}$}} & \multicolumn{2}{|c|}{$\begin{array}{c}\text { Moderate } \\
\text { problem } \\
\text { solving } \\
\text { skills(42-48) }\end{array}$} & \multirow{2}{*}{\multicolumn{2}{|c|}{$\begin{array}{c}\text { High } \\
\text { problem } \\
\text { solving } \\
\text { skills(49-64) }\end{array}$}} & \multirow[b]{3}{*}{ No. } & \multirow[b]{3}{*}{$\%$} & \\
\hline & & & No. & $\%$ & & & & & \\
\hline & N0. & $\%$ & & & No. & $\%$ & & & \\
\hline $\begin{array}{l}\text { Low NTS } \\
\text { perception }(0 \text { - 42) }\end{array}$ & 29 & 85.3 & 3 & 8.8 & 2 & 5.9 & 34 & 100 & $\begin{array}{l}\mathrm{LR}=65.8 \\
\mathrm{P}=0.000\end{array}$ \\
\hline $\begin{array}{l}\text { Moderate NTS } \\
\text { perception }(43-50)\end{array}$ & 4 & 100 & 0 & 0 & 0 & 0 & 4 & 100 & HS \\
\hline $\begin{array}{l}\text { High NTS } \\
\text { perception (51 -66) }\end{array}$ & 36 & 20 & 40 & 22.2 & 104 & 57.8 & 180 & 100 & \\
\hline Total & 69 & 31.7 & 43 & 19.7 & 106 & 48.6 & 218 & 100 & \\
\hline
\end{tabular}

\section{LR= Likelihood Ratio $\quad$ HS=High significant}

Table 3 highlighted that majority of nursing students with low NTS perception showed low PSS level (85.3\%), while $100 \%$ of nursing students with moderate NTS perception (43 -50) showed low PSS level. Among nursing students with high NTS perception, approximately two thirds of them showed high problem solving skill (57.8\%), and one fifth of them $(20 \%)$ showed Low problem solving skill. There was highly significant $(\mathrm{P}=0.000)$ difference between total NTS perception levels among nursing students and their problem-solving skill levels during COVID-19 disaster.

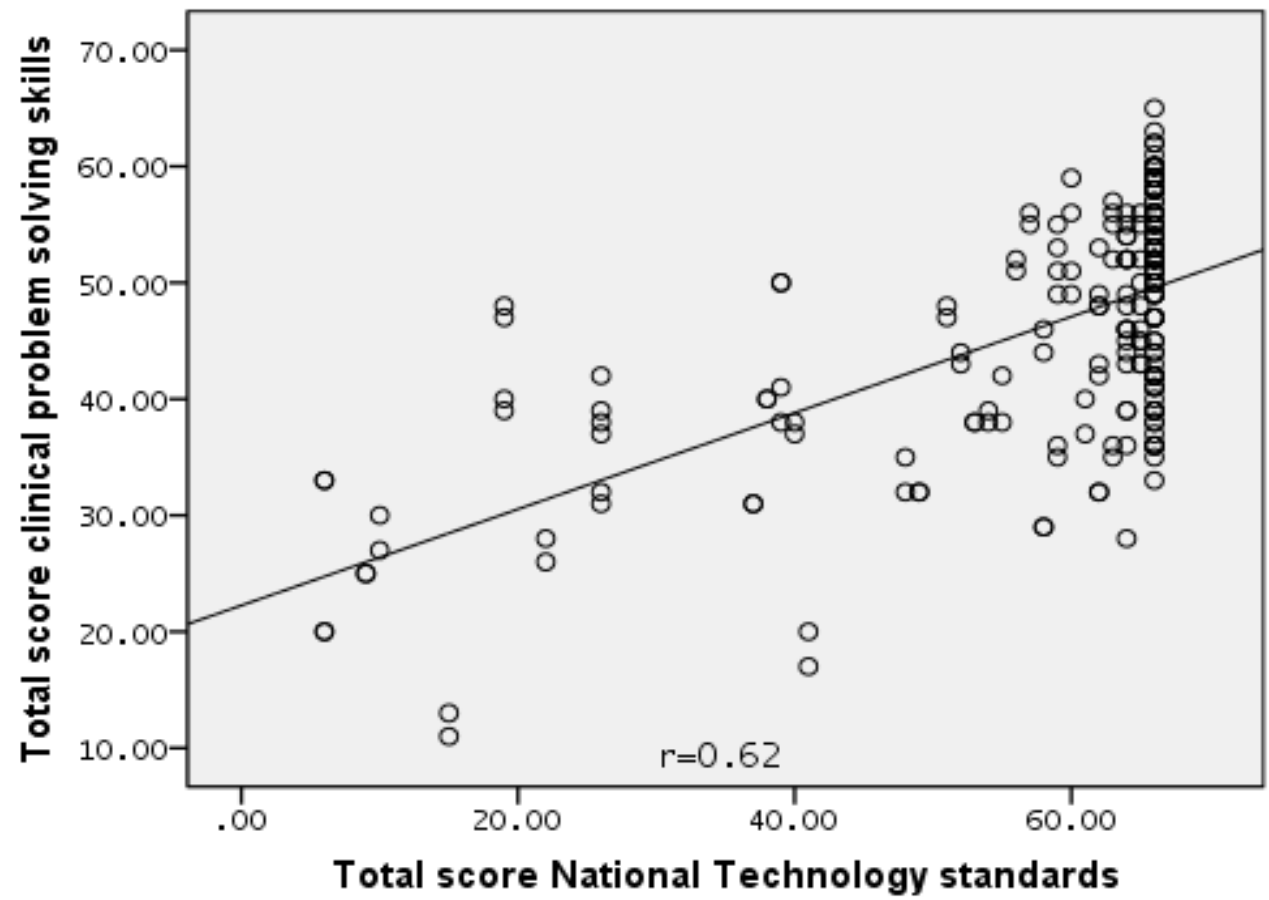

Figure 3. Correlation coefficient ( $\mathrm{r}=0.62)$ between total score National Technology Standard (as independent variable), and total score problem solving skill (as dependent variable) among nursing students. 
Figure 3 demonstrated a positive moderate correlation between total score National Technology Standard (as independent variable), and total score problem solving skill (as dependent variable) among nursing students during COVID-19 disaster.

Table 4. Correlation coefficient between total score NTS and each of total score problem solving skill, and its five subscales.

\begin{tabular}{|c|c|c|c|c|c|c|c|c|c|c|c|c|}
\hline & \multicolumn{2}{|c|}{$\begin{array}{l}\text { Total score } \\
\text { problem solving } \\
\text { skills }\end{array}$} & \multicolumn{2}{|c|}{$\begin{array}{c}\text { Total score } \\
\text { problem1 }\end{array}$} & \multicolumn{2}{|c|}{$\begin{array}{l}\text { Total score } \\
\text { problem } 2\end{array}$} & \multicolumn{2}{|c|}{$\begin{array}{l}\text { Total score } \\
\text { problem3 }\end{array}$} & \multicolumn{2}{|c|}{$\begin{array}{l}\text { Total score } \\
\text { problem4 }\end{array}$} & \multicolumn{2}{|c|}{$\begin{array}{l}\text { Total score } \\
\text { problem5 }\end{array}$} \\
\hline $\begin{array}{l}\text { total score } \\
\text { National } \\
\text { Technology } \\
\text { Standard }\end{array}$ & 0.62 & 0.0001 & 0.64 & 0.0001 & 0.56 & 0.000 & 0.55 & 0.000 & 0.05 & 0.39 & 0.47 & 0.000 \\
\hline
\end{tabular}

Table 4 showed positive moderate correlation with high significant association between total score National Technology Standard and each of Total score problem solving skill, Total score problem1, Total score problem 2, Total score problem3, and Total score problem5 Total score problem1 ( $\mathrm{p}=0.000$ for each). However, there was no significant correlation between total score National Technology Standard and Total score problem4(r=0.05, p=0.39).

3.5 Relationship between Application of National Technology Standards as Perceived by Nursing Students as well as Problem Solving Skill during COVID 19, and Their Demographic Characters

Table 5. Relationship between Application of National Technology Standards as perceived by nursing students as well as problem solving skill during COVID 19, and their demographic characters $(\mathrm{N}=218)$

\begin{tabular}{|c|c|c|c|c|c|c|}
\hline \multicolumn{2}{|c|}{ Socio-demographic characters } & \multirow{2}{*}{$\begin{array}{l}\text { Total } \\
\text { N0 }(\%)\end{array}$} & Total score' of National & \multirow[t]{2}{*}{$\mathrm{P} 1$} & Total score of & \multirow[t]{2}{*}{ P 2} \\
\hline & & & Mean \pm SD & & Mean \pm SD & \\
\hline \multirow[t]{2}{*}{ Age (years): } & $21-22 \mathrm{Y}$ & $150 \quad(68.8)$ & $59.6 \pm 14.9$ & 0.01 & $47.8 \pm 9.2$ & 0.001 \\
\hline & $23-25 \mathrm{Y}$ & $68 \quad(31.2)$ & $53.9 \pm 17.3$ & & $42.2 \pm 11.4$ & \\
\hline \multicolumn{7}{|l|}{$\mathrm{X} \pm \mathrm{SD}$} \\
\hline \multicolumn{7}{|l|}{$22.2 \pm 1.1 \mathrm{Y}$} \\
\hline \multirow[t]{2}{*}{ Gender: } & Females & $182 \quad(83.5)$ & $57.7 \pm 16.2$ & 0.67 & $45.8 \pm 10.1$ & 0.47 \\
\hline & Males & $36 \quad(16.5)$ & $58.9 \pm 14.5$ & & $47.2 \pm 10.8$ & \\
\hline \multirow[t]{3}{*}{ Residence: } & Rural & $184 \quad(84.4)$ & $58.4 \pm 15.4$ & 0.25 & $45.9 \pm 9.6$ & 0.65 \\
\hline & Urban & $34 \quad(15.6)$ & $55 \pm 18.1$ & & $46.8 \pm 13.2$ & \\
\hline & Total & $218 \quad 100 \%$ & $57.9 \pm 15.9$ & & $46.1 \pm 10.2$ & \\
\hline
\end{tabular}

P1=Comparison between each sociodemographic item and total score of National Technology Standard inventory. P2=Comparison between each sociodemographic item and total score of problem solving skill inventory.

The table 5 demonstrated that younger nursing students (21- 22 years) showed a higher mean total NTS (59.6 \pm 14.9$)$ than older age group (23-25 years), the difference was significant statistically $(\mathrm{P}<0.01)$. A higher significant difference was observed among the two age groups regarding mean total PSS $(\mathrm{P}<0.001)$. Concerning gender, male nursing students showed higher nonsignificant mean total NTS and PSS ( $\mathrm{P}=>0.05$ for each). Nursing students living at rural areas showed a higher but insignificant mean NTS $(58.4 \pm 15.4)$, and nurses living in urban area showed a higher nonsignificant mean PSS $(46.8 \pm 13.2)$, ( $\mathrm{P}>0.05$ for each).

\section{Discussion}

The educational technology standards which are developed by International Society for Technology in Education standards for teaching staff and students (the ISTE Standards) represent important framework in point of using technology effectively in teaching and learning processes and are used in widespread by universities, educational institutions and schools (Simsek \& Yazar, 2016). Nursing education requires problem solving ability that is able to 
perform efficiently in various nursing situations. The development of a problem-solving approach to nursing students has been one of the more important changes in nursing education during the last decade (Terzioglu,2006). Problem solving is the ability that is able to recognize hard obstacles and seek a solution with systematic process. Efficient nursing service needs the study of improvement of problem solving ability (Sook \& Hyun ,2014).

The current study aimed to assess the application of national education technology Standards As perceived by nursing student and its relation to their problem solving skill during COVID 19 disaster. Regarding Application of national education technology standards, the study indicated that the grand total mean and range of nursing students' perception of it was $(57.5 \pm 15.4)$. Moreover, the high percentage of high perception $(85.3 \%)$ was to standard 2 (a digital student). Regarding the total levels of application of national education technology standards as perceived by nursing students, the study revealed that the majority of nursing students $(82.6 \%)$ have high level of perception regarding application of these standards. Furthermore, only $(1.8 \%)$ has low level of perception regarding it.

It may explain from researchers' points of views that faculty of nursing; Menoufia University has attained quality accreditation from six years that result in application of quality standards regarding education process for both teaching staff and students. Moreover, students have skills and experiences of education technology as nursing student curriculum in the faculty include course of computer and technology from first grad until fourth grad. Moreover, the faculty of nursing began to use electronic learning before COVID19 with little application. Also, student in our age had used electronic and internet communication method and instruments from they are children as we are in the technological age.

The study finding is supported by Hakami (2019) study which aimed determine the availability of international standards for education technology (ISTE) among students at the Faculty of Education, Umm Al-Qura University. the size of sample study was (458) students. This study stated that the degree of availability of the criteria was average from the students' point of view. In addition, the study finding is in agreement with those of Virtič (2009), and Yasaka $\&$ Alias (2015).

On the other hand, the study is in disagreement with Ayad \& Ajrami (2017) study. That aimed to identifying the degree of application of ISTE standards for both students and teachers in a group of colleges of technical education in Palestine. The study used a set of questionnaires to the sample members, which consisted of 71 teachers, and 186 students. The results of the study were that the ISTE standards are applied to a low degree for both students and teachers. Furthermore, the result of the study differ with those of Chinien (2003) and Hinnawi (2010).

Furthermore, Sharifi (2010) whose study aimed to use a program to prepare students at King Saud University to employ technology in education according to ISTE standards. The study found that there is a gap between the actual reality of students 'use of technology and technologies included in the ISTE standards, and the presence of a lack of technical qualification for students, and the study recommended the need to improve the level of colleges by achieving ISTE standards in preparing students technically and working to align them locally.

Regarding problem solving skill of nursing student during COVID 19 disaster, as noticed in the result the grand total mean and range of nursing students' five problem solving skill categories was $(46.1 \pm 10.2)$. Moreover, the high percentage of high perception $(43.1 \%$ ) was to problem solving skill category four (Put the solution into practice implementation). While the problem solving skill category five (Evaluate the solution) has high percentage (43.1\%\%) of low perception of application. Furthermore, the more of half of nursing students have high and moderate level regarding problem solving skills. Furthermore, only (31.7\%) has low level regarding it. The high percentage of nursing students (48.6\%) had high level problem solving skill.

These results may be due to many factors which increase problem solving skill. One of these factors, nursing curriculum that nursing students learned in the faculty include course of nursing administration that contain subject of problem solving and decision making. In addition, from grade to fourth grade students are prepared to be creative, and have critical thinking and problem solving skills.

The study findings were supported by Sook \& Hyun (2014) study. The aim of this study was to assess the relationship between problem solving ability, professional self-concept, and critical thinking disposition of nursing students. The findings showed that problem solving ability scores were higher in bachelor students, at 4.03 , than in diploma students, at $3.90(\mathrm{p}=.047)$. On the other side, Ancel (2016) study differ with study result. The study was to examine the effect of problem-solving training on the problem-solving skills and self-efficacy of nursing students. The students' PSI total scores were determined as $87.0 \pm 16.7$ before training (low between 81 and 192).

Moreover, the study result is unsupported by Cetin et al. (2018) study. The aim of that study was to assess self-efficacy and problem solving competencies of students of Health Sciences Faculty. The study included 150 students studying 
in 4th grade who completed the questionnaire completely. According to the findings, it was determined that the students had a low level of self-efficacy perception and problem solving competencies. The study finding is in disagreement with study done by Moshirabadi et al. (2015) to determine the perceived problem solving skill of Iranian nursing students. Findings showed that the mean score of this skill in fourth year students $(84.18 \pm 27.47)$ was less than other students.

Regarding answer the research question about is there a relationship between application of national education technology standards as perceived by nursing student and their problem solving skills during COVID 19 disaster. The result highlighted that there was highly significant $(\mathrm{P}=0.000)$ difference between total national technology standards perception levels among nursing students and their Clinical problem-solving skills levels during COVID-19 disaster. Furthermore, the results demonstrated a positive moderate correlation between total score National Technology Standard (as independent variable), and total score clinical problem solving skills (as dependent variable) among nursing students during COVID-19 disaster.

In addition, the research findings ascertain the previous results as these showed a positive moderate correlation with high significant association between total score national technology education standard and each of total score problem solving skill, Total score problem1, Total score problem2, Total score problem3, and Total score problem5 Total score problem 1 ( $\mathrm{p}=0.000$ for each). However, there was no significant correlation between total score National Technology Standard and Total score problem $4(\mathrm{r}=0.05, \mathrm{p}=0.39)$.

It may be explained by the researchers that National Education Technology Standards for students focus on problem solving criteria. As problem solving skills is considered very important skills that all student must have. Using Education Technology prepare students to be critical thinker, creative, problem solver and these skills very important for nursing students. Moreover, students who understand digital technology systems let them to employ productively and effectively in the learning process.

Many literatures have supported these results. Sroeckl (2016) reported that Education Technology develops and enhances the thinking and realization of the global citizen because it allows knowledge on the world level through the processes of communication, participation and cooperation. It makes students use technology with their lives and learn together, and the learning goals have become linked to real and practical life instead of the traditional theoretical goals. Moreover, Taylor (2000) Study assert that problem solving education has a significant effect on problem solving skills.

Regarding the relationship between application of national education technology standards as perceived by nursing students as well as problem solving skill during COVID19, and their demographic characters. The result demonstrated that younger nursing students (21- 22 years) showed a higher mean total national education technology standards (59.6 \pm 14.9 ) than older age group (23-25 years), the difference was significant statistically ( $\mathrm{P}<0.01)$. A higher significant difference was observed among the two age groups regarding mean total problem solving skills $(\mathrm{P}<0.001)$. Concerning gender, male nursing students showed higher non-significant mean total NTS and problem solving skills $(\mathrm{P}=>0.05$ for each).

Study findings is supported by Study done to assess the availability of international standards for education technology (ISTE) the difference of both from gender, specialization, and the academic level in the availability of standards for (458) students, the results indicated that there were no differences to the degree of availability of criteria for the difference in gender or specialization (Hakami, 2019). In another point, the study result is unsupported by Shahzad et al.(2020c). The study objective is to check the difference between male and female E-learning portals' accessibility among the students' perspective. The study included service quality, system quality, information quality, user satisfaction, system use, and E-learning portal success. The findings of the study reveal that males and females have a different level of in terms of usage of towards E-learning portals.

\section{Conclusion}

In the 21 st century, technology is evolving more rapidly than ever. The younger generations, including undergraduate nursing students, live daily lives equipped with highly advanced mobile technology, challenging nursing educators to incorporate mobile technology in education to improve the learning outcomes of students [Risling (2017) and O'Connor et al (2015)].

In the light of the present study findings, it can be concluded that the majority of nursing students $(82.6 \%)$ have high level of perception regarding application of these standards. On the other hand, only (1.8\%) has low level of perception regarding it. Moreover, the high percentage of nursing students $(48.6 \%)$ had high level problem solving skill. Furthermore, the results demonstrated a positive moderate correlation between total score national education Technology Standard (as independent variable), and total score problem solving skill (as dependent variable) among 
nursing students during COVID-19 disaster. Finally, the result demonstrated that significant difference was observed among the two age groups regarding mean of national education Technology Standard and problem solving skill.

\section{Implications for Practice}

Forneris \& Tiffany (2017) stated that technology moves teaching strategies in a direction that engages the learner. In addition, it will challenge students to be critical thinkers, problem-solvers, collaborators, and lifelong learners. Moshirabadi et al. (2015) highlighted that nursing graduates should have the ability to creatively solve problems and make decisions, as these skills assist them with recognizing and evaluating situations that require prompt attention.

Based on the findings of the study, the following recommendations are proposed; assess application of national education technology standards for teaching staff and administrative system, examine the effectiveness of education technology and if there is any obstacles of electronic learning. Moreover, assess the relationship between application of these standards and other skills which are necessary for nursing students like communication, and critical thinking. In addition, periodic updates and training on the new changes in education technology for both nursing students and teaching staff.

\section{Limitations}

The most important limitation of this study is that the research data were collected only from one grade from nursing collage. Therefore, selecting sample from different grades and different nursing faculties recommended for future studies to generalize the findings.

\section{Authors' contribution}

Both authors worked at all research process.

\section{Acknowledgements}

We would like to thank all participant nursing students for their cooperation and help during data collection.

\section{Conflict of Interest}

The authors declare no conflict of interest.

\section{Source of funding}

This research has not received any funding.

\section{References}

Adams, D., Sumintono, B., Mohamed, A., \& Noor, N. S. M. (2018). E-learning readiness among students of diverse backgrounds in a leading malaysian higher education institution. Malaysian Journal of Learning and Instruction, 15(2), 227-256, Google Scholar.

Al-Ani, T. A., \& Al-Jumaili, A. J. (2000). Teaching and vocational training methods. Tripoli: The Arab Center for Vocational Training and Teacher Training. http://librarycatalog.bau.edu.lb/cgi-bin/koha/opac

Al-Fleet, A. A., \& Aql, M. S. (2019). The effectiveness of a training program based on ISTE standards) in developing educational competencies of female teachers at the Faculty of Education - Islamic University of Gaza. Master Thesis, College of Education, Islamic University, Palestine. Retrieved from. https://library.iugaza.edu.ps/thesis/127056.pdf

AL-Zabon, M. S., \& Al-Ajlouni, K. I. (2015). The effect of e-learning on improving self-learning skills and problem solving for students of the Computer Skills 2 course at the International Islamic Science University. PhD thesis, College of Graduate Studies, International Islamic Science University.

Al-Zobaie, E. M., \& Al-Janabi, I. H. (2003). Developing technical education and vocational training curricula. Tripoli: The Arab Center for Vocational Training and Teacher Preparation.

Ancel, G. (2016). Problem-Solving Training: Effects on the Problem-Solving Skills and Self-Efficacy of Nursing Students. Eurasian Journal of Educational Research, 64, 231-246. https://doi.org/10.14689/ejer.2016.64.13

Ayad, F. I., \& Ajrami, S. J. (2017). The Degree of Implementing ISTE Standards in Technical Education Colleges of Palestine. The Turkish Online Journal of Educational Technology, Vol 16, No 2, 107-118.

Azzi-Huck, K., \& T. Shmis. (2020). Managing the impact of COVID-19 on education systems around the world: How countries are preparing, coping, and planning for recovery. 
Bajabaa, A. S. (2017). Influential Factors and Faculty Members Practices in technology Integration Using ISTE standards for teacher preparation at Taibah University-Saudi Arabia. PHD. Kansas State University-USA https://library.iugaza.edu.ps/thesis/127056.pdf

Bixler, B., \& Land, S. (2010). Supporting College Students' Ill-Structured Problem Solving in a Web-Based Learning Environment. Journal of Educational Technology Systems, Vol 39, No (1), 3-15. https://doi.org/10.2190/ET.39.1.b

Cetin, S. Y., Erel, S., \& Ozalp, O. (2018). Assessment of problem solving proficiencies with self-efficacy perceptions of students in faculty of health sciences of cyprus international university SHS Web of Conferences 48, 01025 (2018) https://doi.org/10.1051/shsconf/20184801025

Chinien, C. (2003). Analytical survey: The use of ICTs in technical and vocational education and training. UNESCO Institute for Information Technologies in Education, United Nations Educational, Scientific and Cultural Organization, Moscow.

Chopra, G., Madan, P., Jaisingh, P., \& Bhaskar, P. (2019). Effectiveness of E-learning portal from students' perspective: A structural equation model (SEM) approach. Interactive Technology and Smart Education,16(2), 94-116. https://doi.org/10.1108/ITSE-05-2018-0027

Curwin, R. L., Mendler, A. N., \& Mendler, B. D. (2018). Discipline With dignity: How to build responsibility, relationships, and respect in your classroom (4th ed). Alexandria, VA: Association for super-viaion and Curriculum, Development (ASCD).

Dondlinger, M. J., McLeod, J., \& Vasinda, S. (2016). Essential Conditions for Technology-Supported StudentCentered Learning: An Analysis of Student Experiences With Math Out Loud Using the ISTE Standards for Students. Journal of Research on Technology in Education, Vol. 48, No. 4, pp. 258-273. DOI: $10.1080 / 15391523.2016 .1212633$

Forneris, S., \& Tiffany, J. (2017). Future of technology in nursing education part 1: The what and why of technology use in today's nursing student. NLN Nursing EDge. NLN Center for Innovation in Simulation and Technologyhttps://nlnteq.org/2017/09/05/future-of-technology-in-nursing-education-part-1-the-what-and-whyof-technology-use-in-todays-nursing-student/

Hakami, H. B. M. (2019). The extent to which the standards of the International Society for Technology in Education (ISTE) have been fulfilled by students of the College of Education at Umm Al-Qura University. Journal of the Faculty of Education, Assiut University, Vol35, No 1, 22-1. https://library.iugaza.edu.ps/thesis/127056.pdf

Helen, K. B., John, D., \& Jamie, A. (2009). High-fidelity Simulation in Teaching Problem Solving to 1st-Year Nursing Students. A Novel of Use of the Nursing Process. Clinical Simulation in Nursing, Volume 6, No (3), 87-95. https://doi.org/10.1016/j.ecns.2009.07.005

Hinnawi, Hamid (2010). The role of twelfth grade technology book in equipping students with some global standards for information technology (Unpublished master thesis), the Islamic University, Gaza-Palestine.

ISTE (2016). ISTE standards at ISTE website. Retrieved July 11, 2016, from https://www.iste.org/standards

Kurt, A. A., Coklar, A. N., Kllicer, K., \& Ylldirim, Y. (2008). Evaluation of the skills of K-12 students regarding the national educational technology standards for students (NETS*S) in Turkey. The Turkish Online Journal of Educational Technology, vol 7, NO 3, 6-14. Retrieved March 26, 2019, from https://www.researchgate.net/publication/238091451_Evaluation_of_the_skills_of_Kstudents_regarding_the_national_educational_technology_standards_for_students_NETSS_in_Turkey

Landers, M. (2000). The theory-practice gap in nursing: The role of the nurse teacher. Journal of advanced nursing. 32(6), 1550-1556. https://doi.org/10.1046/j.1365-2648.2000.01605.x

Maphalala, M. C., \& Adigun, O. T. (2020). Academics' Experience of Implementing E-Learning in a South African Higher Education Institution. International Journal of Higher Education Vol. 10, No. 1, 2021. doi:10.5430/ijhe.v10n1p1 URL: https://doi.org/10.5430/ijhe.v10n1p1

Mohammed, S. E. (2017). Assessment of Problem Solving Skills And Factors Influencing Decision Making Among Nursing Management Staff. Master degree. Banha university, Egypt.

Moshirabadi, Z., Seyedfatemi, S., Borimnejad, L., \& Haghani, H. (2015). The Perceived Problem Solving Skill of Iranian Nursing Students August 2015. Volume 1. Number 3, Client-Centered Nursing Care. https://doi.org/10.1016/j.eurpsy.2016.01.1932 
O'Connor, S., \& Andrews, T. (2015). Mobile technology and its use in clinical nursing education: a literature review. J Nurs Educ, 54(3), 137-144. [PubMed] [Google Scholar] https://doi.org/10.3928/01484834-20150218-01

Octaberlina, R., \& Muslimin, A. (2020). EFL Students Perspective towards Online Learning Barriers and Alternatives Using Moodle/Google Classroom during COVID-19 Pandemic. International Journal of Higher Education Vol. 9, No. 6; 2020. https://doi.org/10.5430/ijhe.v9n6p1

Oermann, M. H. (2015). Technology and Teaching Innovations in Nursing Education Engaging the Student. Nurse Educator. Volume 40 \& Number 2 \& March/Apri 1 2015. https://doi.org/10.1097/NNE.0000000000000139

Oldenburg, N. L., \& Hung, W. C. (2010). Problem solving strategies used by RN-to-BSN students in an online problem-based learning course. J Nurs Educ, 49(4), 219-22. doi: 10.3928/01484834-20091118-01. Epub 2010 Apr 7. PMID: 20415329. https://doi.org/10.3928/01484834-20091118-01

Oviawe, J. (2016). Information and Communication Technology in Technical Education. Advances in Social Sciences Research Journal, Vol 3, No 5, 70-79. https://doi.org/10.14738/assrj.35.2033

Rahman, H. (2014). The Role of ICT in Open and Distance Education, Turkish Online Journal of Distance Education, Vol 15, No 4, 162-169. https://doi.org/10.17718/tojde.47700

Risling, T. (2017). Educating the nurses of 2025: technology trends of the next decade. Nurse Educ Pract, 2017, 22, 89-92. [PubMed] [Google Scholar] https://doi.org/10.1016/j.nepr.2016.12.007

Sammour, S. G., \& Al-Qaisi, T. K. (2011). The effect of using problem solving method on developing practical training skills for students of nursing education in community colleges and their attitudes towards practical training. Master Thesis, College of Educational and Psychological Sciences, Amman Arab University, Amman. https://search.emarefa.net/ar/search?append=PERSON_FILTER_AR_NAME_ss\%3A\%22\%D8\%A7\%D9\%84 $\% \mathrm{D} 9 \% 85 \% \mathrm{D} 9 \% 82 \% \mathrm{D} 8 \% \mathrm{AF} \% \mathrm{D} 8 \% \mathrm{~A} 7 \% \mathrm{D} 8 \% \mathrm{AF} \% \mathrm{D} 9 \% 8 \mathrm{~A} \% \mathrm{D} 8 \% \mathbf{C}+\% \mathrm{D} 8 \% \mathrm{~A} 3 \% \mathrm{D} 8 \% \mathrm{AD} \% \mathrm{D} \% 85 \% \mathrm{D} \% \% \mathrm{~A}$ $\mathrm{F}+\% \mathrm{D} 9 \% 85 \% \mathrm{D} 8 \% \mathrm{AD} \% \mathrm{D} 9 \% 85 \% \mathrm{D} 8 \% \mathrm{AF} \% 22$

Serin, O. (2011). The Effects of The Computer-Base Instruction on The Achievement and Problem Solving Skills of science and technology Students. TOJET: The Turkish Online Journal of Educational Technology. Vol 10, No 1, 183-201.

Shahzad, A., Chin, H. K., Altaf, M., \& Bajwa, F.A. (2020a). Malaysian SMEs performance and the use of e-commerce: A multi-group analysis of click-and-mortar and pureplay E-retailers. Pakistan Journal of Commerce and Social Sciences (PJCSS), 14(1), 1-33.

Shahzad, A., Hassan, R., Aremu, A., Hussain, A., \& Lodhi, R. (2020c). Effects of COVID 19 in E learning on higher education institution students: the group comparison between male and female. Quality \& Quantity. https://doi.org/10.1007/s11135-020-01028-z

Sharifi, H. (2010). A proposed training program in preparing students of the College of Education at King Saud University to integrate technology with education in accordance with the standards of the International Society for Technology in Education ISTE, PhD thesis, College of Education, King Saud University.

Simsek, O., \& Yazar, T. (2016). Education technology standards self-efficacy (ETSSE) scale: A validity and reliability study. Eurasian Journal of Educational Research, 63, 311-334. https://doi.org/10.14689/ejer.2016.63.18

Sook Kim, K., \& Hyun Choi, J. (2014). The Relationship between Problem Solving Ability, Professional Self Concept, and Critical Thinking Disposition of Nursing Students. International Journal of Bio-Science and Bio-Technology Vol.6, No.5 (2014), 131-142. https://doi.org/10.14257/ijbsbt.2014.6.5.13

Sroeckl, S. (2016). Five reasons why the 2016 ISTE Standards for students matter. Retrieved May 27, 2019, from https://www.iste.org/explore/ISTE-Standards-in-Action/Five-reasons-why-the-2016-ISTE-Standards-forStudents-matter.

Taylor, C. (1997) Problem solving in clinical nursing practice. Journal of Advanced Nursing, 26, 329-326. Wiley Online Library CAS PubMed Web of Science®Google Scholar. https://doi.org/10.1046/j.13652648.1997.1997026329.x

Terzioglu, F. (2006). "The perceived problem-solving ability of nursing managers", Journal of Nursing Management, Vol. 14, No. 5, 340-347. https://doi.org/10.1111/j.1365-2934.2006.00551.x

Virtič, M. (2009). Model of ICT implementation in the technical education. Problems of Education in the 21 st Century, 14, 144-158. 
Yasaka, Z., \& Alias, M. (2015). ICT integrations in TVET: Is it up to expectations? Fourth World Congress onTechnical and Vocational Education and Training, 5th -6th November 2014, Malaysia. Procedia - Social and Behavioral Sciences, 204, 88-97. https://doi.org/10.1016/j.sbspro.2015.08.120

World Health Organization (2019). Retrieved July 21, 2019, from https://www.who.int/emergencies/diseases/novelcoronavirus-2019

21CLI (21st Century Learning International) (2018). ISTE Standards Professional Development. https://www.21clearning.com/iste-standards-professional-development/

\section{Copyrights}

Copyright for this article is retained by the author(s), with first publication rights granted to the journal.

This is an open-access article distributed under the terms and conditions of the Creative Commons Attribution license (http://creativecommons.org/licenses/by/4.0/). 